\title{
Model Penyesuaian Diri Mahasiswa Baru
}

\section{A New Student Adjusment Model}

\author{
Muhammad Jamaluddin \\ Universitas Islam Negeri Maulana Malik Ibrahim, Malang \\ jamaluddi@psi.uin-malang.ac.id
}

\begin{abstract}
Abstrak
Salah satu tugas kehidupan seseorang secara psikologis itu diantaranya adalah harus mampu melakukan penyesuaian diri secara terus menerus dengan lingkungan dan perkembangan yang ada. Penyesuaian diri ini sangatlah dibutuhkan oleh setiap individu terutama pada individu yang sedang menginjak masa remaja, karena jika permasalahan penyesuaian diri ini tidak teratasi dengan baik, maka akan menimbulkan masalah-masalah baru dalam kehidupannya. Adapun dari penelitian ini didapatkan hasil adanya problematika penyesuaian diri yang meliputi aspek psikologis, akademis, sosial dan demografis. Sementara penyelesaian atas permasalahan atau problematika penyesuaian diri ini diantaranya melalui aspek internal (yakni dengan cara individu atau mahasiswa tersebut membuat goal setting, manajemen diri ataupun berinteraksi social dengan baik) dan eksternal (adanya kebutuhan terhadap pendampingan psikologis dan konseling dari lembaga).
\end{abstract}

Kata kunci: Penyesuaian diri, Mahasiswa baru

\begin{abstract}
One of the psychological tasks of one's life is to be able adjustments continuously to the environment and existing developments. This adjustment is really needed by every one, especially in individuals who are in their teens, because if the adjustment problem is not resolved properly, it will cause a new problems in their lives. The results of this research show that there are adjustment problems which include psychological, academic, social and demographic aspects. while solving the problem or adjustment problem is through internal aspects (by means of the individual or student making goal setting, self-management or social interaction well) and external (the need for psychological assistance and counseling from the institution).
\end{abstract}

Keywords: Self adjusments, New Student

\section{Pendahuluan}

Salah satu makhluk yang sangat unik adalah manusia, karena keunikannya itulah mereka dituntut agar memiliki kemampuan dalam beradaptasi dengan lingkungan sekitarnya. Selain unik, manusia tersebut juga akan mengalami perubahan-perubahan dalam siklus kehidupannya, mulai dari perubahan fisiologis, sosial hingga psikologis. Salah satu fase perkembangan manusia yang mengalami banyak perubahan tersebut adalah fase remaja. Masa remaja merupakan masa dimana seorang remaja mengalami banyak gejolak dengan perkembangan dan perubahan yang dialaminya. Masa ini biasanya disebut dengan "sturm und drang" (topan dan badai), masa yang dipenuhi dengan gejolak emosi dikarenakan banyaknya pertentangan antara dirinya dengan nilai-nilai yang ada. Dampak dari emosi yang bergejolak ini biasanya menyulitkan diri sendiri. Namun pada sisi lain, emosi yang bergejolak ini juga bisa bernilai positif bagi remaja sebagai media untuk menemukan jati diri atau identitas dirinya dengan menjadikan pengalaman hidupnya sebagai pembelajaran agar bisa menentukan tindakan tepat yang kelak akan dilakukannya (Hall dalam Sarwono, 2011). Hurlock (1991) mengatakan bahwa fase pengenalan identitas diri dan pengembangan diri itu biasanya terjadi pada masa remaja. 
Kondisi yang pernah terjadi pada fase anak-anak itu akan semakin berkembang dan kuat pada masa remaja yang kemudian berlanjut di masa dewasa. Sehingga dengan adanya perubahan-perubahan yang remaja alami selama ini, mereka juga menghadapi banyak tugas-tugas perkembangan dan kehidupan yang berbeda dengan tugas-tugas sebelumnya, terutama tugas pada masa anak-anak. Jika semua tugas tersebut bisa terselesaikan secara baik oleh seorang remaja, maka dia dapat mencapai sebuah kepuasan diri dan mampu merasakan penerimaan diri dari tempat ia tinggal. Keberhasilan dalam menjalankan tugas perkembangan tersebut juga akan mempengaruhi keberhasilan sesorang remaja dalam memenuhi tugas-tugas perkembangan di masa yang akan datang. Menurut Havighurst (dalam Hurlock, 1991), seorang remaja harus melalui tugas-tugas perkembangan yang ada kaitannya dengan fungsi belajar itu sendiri, karena pada kenyataannya perkembangan kehidupan yang dijalani oleh individu juga dipandang sebagai usaha untuk belajar tentang norma yang berlaku sekaligus belajar tentang budaya masyarakat yang ada agar mereka memiliki kemampuan yang baik dalam menyesuaikan diri dengan kehidupan nyata. Namun pada kenyataannya terdapat beberapa fakta remaja dalam hal ini adalah seorang mahasiswa yang belum mampu dalam memenuhi tugas fungsi belajarnya dengan baik. Berdasarkan dari hasil wawancara dengan beberapa remaja mahasiswa (25 Januari 2017) didapatkan bahwa mereka banyak mengalami kendala dalam fungsi belajarnya, mulai dari proses belajarnya itu sendiri, adaptasi lingkungan baru, materi yang asing hingga kendala yang berkaitan dengan kegiatan-kegiatan yang belum pernah ia lakukan sebelumnya. Tidak sedikit remaja atau mahasiswa tersebut merasa tertekan dengan kondisi seperti itu yang berdampak pada menurunnya motivasi belajar ataupun prestasi belajar mereka. Hal ini terbukti dengan adanya beberapa hasil atau nilai hasil studi yang tidak memuaskan. Menurut mereka, penurunan ini diantaranya dikarenakan kurangnya kemampuan individu atau remaja tersebut dalam menyesuaikan diri dengan segala sesuatu yang baru yang belum pernah ia alami atau ia ketahui sebelumnya, misalkan suasana dimana ia harus belajar bahasa asing dengan waktu yang panjang, tinggal di sebuah pesantren yang belum pernah ia alami juga, bertemu banyak orang baru dengan berbagai macam suku budaya dan lain sebagainya.

Hal yang sama juga disampaikan oleh Hurlock (1991) bahwa terdapat beberapa masalah yang dialami oleh seorang remaja ketika ia sedang memenuhi tugas-tugas perkembangan tersebut, diantaranya: (1) personal problem (pribadi), masalah ini biasanya terkait dengan kondisi pada saat ia ada di lingkungan keluarga, sekolah, kondisi yang berkaitan dengan fisik remaja, gaya berpakain, kondisi emosi, pergaulan sosial, tugas perkembangan dan nilai-nilai yang berlaku di lingkungan sekitar. (2). Masalah ke-remajaan. Masalah ini biasanya berkaitan dengan kemandirian, penialian yang salah terhadap sesuatu dan lain sebagainya sebagai akibat dari status yang tidak jelas pada diri seorang remaja. Hurlock (1980) menambahkan bahwa penyesuaian sosial itu sendiri merupakan salah satu tugas perkembangan yang paling sulit yang dihadapi di oleh seorang remaja. Kondisi seperti ini terkadang membuat ketidakstabilan pada diri remaja dan akan menimbulkan berbagai permasalahan sebagai akibat dari adanya penyesuaian terhadap hal baru (baik terkait dengan perilaku maupun harapan yang baru pula). Meskipun hal ini tidak dialami oleh semua remaja, paling tidak, kondisi ini akan berjalan sampai beberap waktu (dalam Estiane, 2015).

Meskipun demikian, banyak pula dari para remaja atau mahasiswa tersebut yang tidak membutuhkan banyak waktu untuk secepatnya merubah diri menjadi lebih baik dengan cara melakukan penyesuaian diri dengan lingkungan sekitarnya. Kondisi ini selain mampu membuat tingkat motivasi dan prestasi belajar menjadi naik, juga mampu mengurangi simptom atau keluhan selama ia melakukan penyesuaian diri tersebut (wawancara tanggal 27 Januari 2017). Oleh karena itu, dengan adanya permasalahan dan beberapa perubahan itu, seorang remaja dituntut harus memiliki kemampuan dalam menyesuaikan diri dengan segala perubahan yang ada terutama perubahan yang berkaitan dengan tugastugas belajarnya. Penyesuaian diri ini pada kenyataannya adalah sebuah interaksi antar individu yang berjalan secara kontinyu (terus menerus), baik itu interaksi dengan dirinya sendiri, orang lain, maupun dunia sekitarnya. Seorang remaja bisa disebut sebagai individu dengan memiliki kemampuan penyesuaian diri yang baik jika ia mampu beradaptasi atau menyesuaikan diri dengan lingkungan sekitar, jika ia merasa puas dengan kehidupannya, tidak merasa stres, serta mampu terbebas dari berbagai hal yang membuat cemas yang berakibat terganggunya sebuah fase perkembangan. Dan sebaliknya, seorang remaja akan mengalami gangguan penyesuaian diri ketika seorang remaja itu tidak memliki kemampuan dalam mengatasi setiap masalah yang dihadapinya dengan memberikan respon atau reaksi yang kurang tepat, kondisi emosi yang tidak terkontrol, dan keadaan yang dianggapnya kurang menguntungkan dirinya.

Kehidupan itu sendiri pada kenyatannya juga akan mendorong seseorang untuk terus-menerus melakukan penyesuaian diri. Fahmi (1977) mengatakan bahawa penyesuaian diri itu adalah kondisi 
dinamis yang berjalan secara kontinyu dengan memiliki tujuan agar dapat mengarahkan sebuah perilaku demi mendapatkan kehidupan yang seimbang antara diri dan lingkungannya. Penyesuaian diri ini sangatlah dibutuhkan oleh setiap individu terutama pada individu yang sedang menginjak masa remaja, karena pada fase ini biasanya akan banyak mengakibatkan perubahan-perubahan dan goncangan dalam diri remaja tersebut, sehingga dalam proses penyesuaian diri ini, perasaan akan diterima oleh lingkungan merupakan sesuatu yang sangat dibutuhkan oleh seorang remaja. Adanya perasaan diterima oleh banyak orang sangatlah penting buat seorang remaja. Seorang remaja yang sudah diterima di lingkungannya akan merasakan diri senang, puas akan kehidupan dan memliki percaya diri yang tinggi, namun sebaliknya, jika seorang remaja yang diabaikan oleh lingkungan sekitarnya, maka ia akan merasakan kekecewaan, perasaan rendah diri, frustasi dan bahkan bisa menimbulkan banyak tingkah laku negatif lainnya seperti tingkah laku agresif dan lain sebagainya (Mapiare, 1982). Berbagai masalah penyesuaian diri remaja sekaligus beberapa perilaku penyesuaian diri yang baik yang remaja lakukan selama ini (sebagaimana dijelaskan di atas) perlu untuk ditindak lanjuti sebagai bahan preventif dan model dalam pemecahan masalah, karena jika permasalahan tersebut tidak mendapatkan perhatian secara lebih sekaligus kurang mendapatkan penanganan yang baik pula, maka dikhawatirkan akan berdampak dengan munculnya masalah baru pada diri remaja yang berhubungan dengan proses pemenuhan tugas atau fase perkembangannya. Oleh karena itu, peneliti tertarik untuk meneliti konsep remaja itu sendiri dan konsep penyesuaian dirinya dengan mengangkat judul "Model Penyesuaian Diri Mahasiswa Baru UIN Maulana Malik Ibrahim Malang)".

\section{Metode Penelitian}

Pendekatan penelitian ini adalah penelitian kualitatif dengan jenis penelitian lapangan (field research), dimana datanya akan banyak menghasilkan data deskriptif berupa kata-kata tertulis atau lisan dari orang yang diamati dijadikan sebagai subyek penelitian (Bodgan dan Taylor dalam Moleong, 1994). Atau dengan kata lain, penelitian kualitatif ini akan menemukan hasil penelitian yang tidak dapat dicapai dengan menggunakan pendekatan angka atau analisa statistika (Strauss dan Corbin, 1997).

Adapun dalam analisa data kualitatif diantaranya dengan prosedur sebagai berikut:

a. Reduksi data

Reduksi data ini digunakan untuk manajamkan, menggolongkan, mengarahkan, membuang yang tidak perlu, dan mengorganisasi data sehingga menjadi sebuah kesimpulan final yang dapat ditarik hasilnya untuk bisa dilakukan verifikasi (Miles, 1992).

b. Penyajian data

Dari penyajian-penyajian data ini, bisa diketahui atau difahami tentang sesuatu yang terjadi selama penelitian berlangsung sekaligus untuk diambil langkah atau tindakan lebih lanjut terkait dengan hasil tersebut (Wahidmurni, 2008).

c. Penarikan kesimpulan

Analisa ini digunakan dengan cara menarik kesimpulan dan menverifikasi data hasil temuan. Dari data yang terkumpul di awal penelitian, peneliti mulai mengarah pada pengambilan kesimpulankesimpulan yang pada mulanya belum begitu jelas, namun dengan menggunakan istilah penelitian dari Strauss (1997) maka kesimpulan penelitian tersebut kemudian semakin detail, kuat dan mendalam (mengakar).

Sementara dalam uji keabsahan data ini menggunakan uji derajat kepercayaan (kredibilitas) dan triangulasi. Menurut Moleong (1994) kredibilitas sebuah penelitian akan didasarkan pada 7 (tujuh) kriteria, yaitu (1) intensitas keikut-sertaan yang lama (panjang), (2) Pengamatan dilakukan secara tekun, (3) Trianggulasi, (4) Adanya sejawat yang melakukan pengecekan, (5) Refrensi yang memadahi sebagai bahan evalusi atau kritik tertulis, (6) Kajian kasus negatif, (7) Pengecekan anggota.

Sementara uji triangulasi adalah teknik yang digunakan peneliti dalam memeriksa keabsahan data dengan melakukan pengecekan kembali data yang ada dengan data di luar penelitian sebagai pembanding terhadap data temuan tersebut. Dalam proses pengecekan dan membandingkan ini, peneliti bisa menggunakan teknik triangulasi sumber, yakni tingkat kepercayaan informasi yang diperoleh atau hasil yang didapat dibandingkan dan dicek lagi secara detail melalui alat dan waktu yang variatif atau berbeda dengan cara: (a) data hasil pengamatan dibandingkan dengan data hasil interview, (b) data yang diperoleh dari orang lain dibandingkan dengan yang sampaikan oleh subyek penelitian (Moleong, 1994). 


\section{Hasil Penelitian}

Penelitian kualitatif ini menemukan hasil sebagai berikut:

a. Problematika penyesuaian diri

Subyek penelitian ini adalah mahasiswa baru yang memiliki berbagai latar-belakang, mulai dari latarbelakang ekonomi, riwayat akademik, demografis dan lain sebagainya. Subyek atau mahasiswa baru tersebut tidak semuanya lulusan pesantren atau Madrasah Aliyah yang dengan mudah bisa menyesuaikan dengan kondisi kampus yang memiliki beberapa program pembelajaran Bahasa Arab dan Ma'had, sehingga subyek yang berlatar belakang dari pendidikan umum (yang belum pernah mendapatkan pembelajaran Bahasa Arab dan tidak pernah tinggal di pesantren) terkadang mengalami kendala dan menemukan permasalahan untuk menyesuaikan diri dengan kondisi tersebut. Diantara kendala atau problematika yang dihadapi adalah dari aspek psikologis (adanya perasaan minder, tidak percaya diri, kurang mampu dalam menyampaikan pendapat, atau kurang mampu bersosialisasi dengan baik). Hal ini diantaranya sesuai dengan yang disampaikan oleh beberapa subyek penelitian yang secara garis besar dijelaskan dan diterjemahkan peneliti dari hasil pengembangan data diantaranya seperti deskripsi-deskripsi di bawah ini:

"ya kadang saya itu malu kalo bertemu banyak orang yang belum pernah saya kenal sebelumnya pak, terlebih kalo saya harus berpendapat. Seperti ketika presentasi juga saya kadang kurang PeDe,,apalagi kalo temen-temen saya ada yang sudah jago waktu presentasi".

Hal yang sama juga ada yang disampaikan oleh subyek terkait dengan ketidakmampuan untuk bersosialisasi secara bersama-sama meskipun menyadari untuk berusaha menjadi lebih aktif dan bersemangat:

"saya kadang merasa ada perasaan minder untuk gabung bersama teman-teman, tapi saya sadar saya harus berani dan semangat seperti mereka agar saya mudah dalam mendapatkan teman dan banyak yang menyukai saya juga sehingga saya tidak merasa "sendirian" sebagai seorang maba (mahasiswa baru)".

Problematika penyesuaian diri yang kedua yang dihadapi oleh mahasiswa baru sebagai subyek penelitian diantaranya adalah terkait dengan akademik. Problematika secara akademik ini seperti jurusan yang dijalani sekarang dianggap tidak sesuai dengan pilihan atau minatnya, adanya perbedaan model pembelajaran antara ketika masih di sekolah menengah dengan di Perguruan tinggi, adanya keharusan untuk tinggal di ma'had kampus dan menyesuaikan dengan peraturan yang ada di ma'had tersebut. Berikut diantara penerjemahan dan pengembangan peneliti dari yang disampaikan oleh subyek penelitian:

"jurusan saya sekarang itu tidak sesuai pak, dulu saya itu pinginnya ambil jurusan A tapi sekarang saya diterima atau kuliah di jurusan B, sehingga kadang gini ini yang membuat saya merasa malas pak"

Hal yang sama juga seperti hasil pengembangan data berikut:

"saya itu belum pernah mondok, tapi sekarang harus tinggal di ma'had kampus, maka saya harus beradaptasi lagi dengan hal baru, apalagi ada peraturan-peraturan yang di ma'had pak yang kadang saya belum terbiasa dengan hal itu".

Kendala penyesuain diri yang lain adalah berkaitan dengan kehidupan sosial. Berdasarkan data dari subyek penelitian didapatkan bahwa kehidupan sosial ini diantaranya ketika subyek dihadapkan pada pribadi-pribadi asing atau baru yang selama ini belum pernah ia kenal sebelumnya, adanya interaksi sosial lawan jenis sebagai kegiatan kelompok atau kerjasama yang sebagian subyek merasa belum siap, dan adanya penyesuaian dengan pergaulan mahasiswa yang perokok dan yang tidak merokok. Hal ini sebagaimana hasil dari pengembangan kesimpulan yang disampaikan oleh subyek berikut:

"perasaan saya ketemu orang baru itu gimana gitu pak, kadang butuh tekad untuk

berkenalan, menjalin hubungan secara baik, cuma ya tadi, gimana gitu rasanya, terutama kalua mau memula......"

Bagitu juga yang berkaitan dengan beberapa mahasiswa yang memiliki kebiasaan merokok. Berikut diantara hasil pengembangan data yang disampaikan oleh subyek:

“.......kalo sudah ketemu teman yang merokok bareng-bareng itu, saya kadang kurang nyaman karena asapnya, terus saya biasanya menghindar atau menjaga jarak pas mereka sedang 


\section{merokok itu, biar saya juga gak kena asapnya tadi itu, apala gi saya dari keccil tidak pernah} meroko......."

Problematika penyesuaian diri yang terakhir adalah penyesuain diri yang berkaitan dengan demografis, seperti cuaca atau iklim di kota Malang yang dingin, bahasa dan dan adat istiadat yang berbeda dengan kondisi subyek atau mahasiswa pada saat mereka masih tinggal di daerah dan keluarga masing-masing. Mahasiswa tersebut memang dari berbagai penjuru daerah bahkan negara, sehingga memang dibutuhkan kemampuan lebih untuk bisa beradaptasi dengan baik antar satu dengan yang lain. Berikut ini salah satu hasil pengembangan data wawancara dan tertulis pada subyek penelitian:

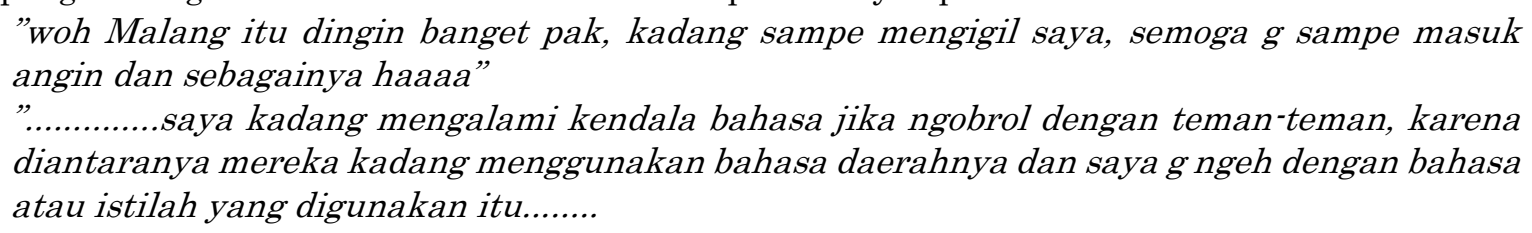

2. Model penyesuaian diri mahasiswa"

Berdasarkan fakta yang didapat dari penelitian ini, maka bisa dipaparkan hasil data model penyesuaian sebagai berikut:

a. Model penyesuaian diri secara Internal

Model penyesuian diri yang dilakuakn subyek penelitian terkait dengan aspek psikologis adalah berusaha dengan sendirinya untuk bisa meningkatkan kepercayaan diri dengan mengikuti segala yang berlaku. Terlebih menurut mereka, kepercayaan diri sangat dibutuhkan untuk bisa menjalankan aktifikas di kampus dengan kendala yang berarti. Selain itu, dalam menyelesaikan permasalahan yang dihadapi terkait dengan kondisi psikologis ini, subyek juga melakukan pemahaman diri (self awerenes) dengan membuat skala prioritas atau goal setting seperti membuat alasan kuliah, target yang diraih, menata niat dan sebagainya. Dengan kesadaran diri terkait dengan tugas perkembangan dalam bentuk kuliah ini juga diharapkan bisa memperlancar proses perkuliahan sekaligus meminimalisir kendala agar tidak berdampak pada aspek lainnya. Hal ini sebagaimana pengembangan data berikut:

“.....meskipun kadang saya merasa agak kurang PeDe, tapi saya terus berusaha untuk kumpul-kumpul aj, bareng-bareng dan ngikuti aja yang ada biar nanti saya merasa nyaman dengan sendirinya....."

“.......ya mau g mau saya harus sadar diri pak, kenapa saya kuliah, kira-kira nanti saya harus seperti apa, tujuan yang akan saya capai juga apa, pokoknya saya harus menata niat sampai selesai kuliah agar saya bisa sukses..."

b. Model penyesuaian diri secara Eksternal

Model penyesuaian berikutnya yaitu secara eksternal dengan melibatkan unsur dari luar karena permasalahan yang dihadapi oleh mahasiswa baru tidak hanya terbatas pada faktor internal saja tetapi juga terkadang terkait dengan adanya unsur luar diri, sehingga dibutuhkan pula model penyesuaian yang berhubungan dengan kondisi luar tersebut. Hasil penelitian ini menunjukkan bahwa dalam menyelesaikan masalah penyesuaian diri yang dihadapi, mahasiswa membutuhkan adanya konseling yang harus diberikan oleh lembaga.

Hasil lain dari penelitian ini terkait dengan model penyesuaian diri yang berkaitan dengan faktor eksternal adalah adanya pendampingan terhadap para mahasiswa baru tersebut, dimana mereka dihadapkan pada lingkungan geografis, lingkungan social, dan lingkungan akademik yang baru sehingga tidak sedikit dari mahasiswa baru tersebut mengalami kendala di awal-awal perkuliahannya. Pendampingan di sini bisa sebagai tindak lanjut dari hasil konseling yang dilakukan oleh para konselor pada konselinya. Dengan adanya pendampingan secara intens, mahasiswa berharap permasalahan yang dihadapi semakin cepat terselesaikan dan teratasi sehingga dalam menjalani kehidupan baru dalam universitas tidak ditemui kendala yang berarti, sekaligus tidak memunculkan malasah-masalah baru karena masalah awal sudah teratasi dengan baik melalui konseling dan pendampingan tersebut. Banyak dari subyek menginginkan adanya pendampingan sebagaimana pemaparan di atas, dengan adanya konseling dan pendampingan selama masa kuliah sangat dibutuhkan, terlebih bagi mereka yang mengalami kendala selama menuntut ilmu di lembaga tersebut. Hal ini sebagaimana hasil pengembangan data dari subyek penelitian: 
“......kadang kalo kita ada masalah, itu belum tau harus kemana pak ceritanya, saya juga $g$. tau kampus ini sudah punya tempat untuk curhat, konseling atau yang seperti itu pokonya, agar kita yang punya masalah kuliah atau lainnya bisa cerita ked an legah gt heee....."

"nek kuliah terus ada pendampingan pas lagi punya masalah itu penting pak, ya misalnya kampus bisa mendampingi itu agar masalah, karena nek sendirian nyelesaiin maasalah juga kadang kita $g$ faham harus ngapain,.........tapi kalo g salah ada dosen wali juga untuk tiap mahasiswa, semoga ini juga bisa bantu nyelesain mahasiswa yang punya masalah tadi pak...

Berdasarkan pemaparan di atas paling tidak ditemukan dua model, diantaranya secara internal (dari diri masing-masing mahasiswa untuk bisa menyelesaikan masalahnya dengan melakukan perubahanperubahan atau kegiatan yang positif yang bisa mendukung penyelesaian masalah tersebut). Yang kedua adalah secara eksternal (yakni luar diri mahasiswa seperti adanya layanan dari unit konseling universitas atau lembaga serta pendampingan pada mahasiswa yang mengalami kendala belajar derngan harapan bisa membantu mahasiswa yang membutuhkan).

\section{Pembahasan}

Menyesuaikan diri di perguruan tinggi selepas bangku sekolah menengah dapat menjadi transisi yang sulit bagi banyak mahasiswa. Masa transisi dari bangku sekolah menuju bangku perkuliahan adalah sebuah proses yang kompleks. Di Indonesia, sebagian besar remaja yang lulus dari sekolah menengah, melanjutkan pendidikannya hingga ke perguruan tinggi (Monks, 2002, dalam Estiane, 2015). Oleh karena it, dalam penelitian ini ditemukan bahwa terdapat problematika dan model penyesuaian diri yang muncul dari mahasiswa baru ketika pertama kali mengikuti kegiatan di Kampus Universitas Islam Negeri Maulana Malik Ibrahim ini:

1. Problematika penyesuaian diri yang muncul pada diri mahasiswa

a. Problematika penyesuaian diri secara psikologis

Manusia adalah salah satu makhluk yang unik, karena keunikannya itulah mereka harus mampu menyesuaikan diri baik secara kejiwaan, lingkungan sosial, dan lingkungan alam sekitarnya. Selain unik, manusia tersebut juga akan mengalami perubahan-perubahan dalam siklus kehidupannya, mulai dari perubahan fisiologis, sosial hingga psikologis. Salah satu fase perkembangan manusia yang mengalami banyak perubahan tersebut adalah fase remaja. Fase remaja biasanya disebut dengan fase "topan dan badai" (sturm and drang), yakni fase emosi yang meledak-ledak, karena merasa adanya perasaan bertentangan dengan nilai-nilai yang ada. Dan perasaan ini adakalanya menyulitkan, baik bagi si remaja itu sendiri maupun bagi orang yang ada di sekitarnya. Meskipun demikian, perasaan tadi juga bisa memberikan manfaat terkait dengan proses pencarian identitas diri seorang remaja. Sehingga pengalaman belajar remaja dalam menentukan tindakan yang tepat diddapatkan dari reaksi orang-orang sekitarnta (Hall dalam Sarwono, 2011).

Hasil penelitian ditemukan bahwa dari permasalahan penyesuaian diri terkait psikologis ini adalah adanya anggapan atau perasaan diri yang introvert terhadap lingkungan dan tuntutan yang ada, sehingga subyek merasa tidak bisa mengikuti dan beradaptasi dengan baik. Kesulitan yang dihadapi subyek penelitian dalam menyesuaikan diri secara psikologis ini disebabkan keterbatasan kemampuan subyek dalam menyampaikan pendapat di depan umum atau mengutarakan isi hati yang dirasa tidak nyaman atau cocok menurut dia. Tidak semua mahasiswa memiliki kemampuan dalam komunikasi secara verbal ini, terlebih bagi mereka yang belum terlatih sebelum ia menempuh pendidikan di sebuah perguruan tinggi, sehingga dampak dari yang subyek rasakan adalah tidak "betah" dengan kondisi yang seperti itu. Hal ini juga didukung oleh penelitian yang dilakukan oleh Nursyahrurahmah (2017) bahwa terdapat hungan yang signifikan antara kepribadian introvert dengan perasaan kesepian remaja. Individu yang berkepribadian introvert biasanya menghindari berhubungan dengan banyak orang dan lebih suka menyendiri. Oleh karena itu, menurut Fortin dkk (2006) jika kondisi seperti ini tidak mendapatkan penanganan, maka dikhawatirkan mahasiswa tersebut bisa meninggalkan perkuliannya (DO/drop out), sehingga pengaruh kemampuan pribadi (personal), dukkungan keluarga dan keterlibatan lembaga sangat dibutuhkan agar tidak terjadi hal negative pada mahasiswa yang bersangkutan. Irfan dan Suprapti (2014) dalam penelitiannya juga menyampaikan hal yang sama bahwa penyesuaian diri itu sendiri juga dipengaruhi oleh kepribadian individu, salah satunya adalah self efficacy, dimana jika individu atau remaja tersebut mampu mengontrol dan menghadapi lingkungan dengan baik dan dengan cara yang positif, maka problematika penyesuaian diri tersebut juga bisa teratasi. 
Schneider (1960) dalam bukunya juga menyebutkan bahwa kepribadian merupakan mind a body yang bisa mempengaruhi seseorang dalam menyesuaikan dirinya dengan lingkungan, jika seseorang tersebut mengalami kendala dalam konsep kepribadiannya tadi, maka hal tersebut akan berpengaruh pada fisiknya dan proses adaptasi dia.

b. Problematika penyesuaian diri secara akademik

Penyesuaian diri secara akademik ini diartikan sebagai kemampuan seseorang dalam mengatasi problematika dan tuntutan yang ada di lingkungan tempat ia belajar demi tercapainya sebuah keselarasan dan keharmonisan (Fitri dan Kustanti, 2018). Bentuk permasalahan penyesuaian diri yang lain adalah terkait dengan akademik. Permasalahan akademik ini dirasakan oleh subyek penelitian ketika ia harus menjalani kuliah yang tidak sesuai dengan jurusan utama yang dipilih sebelumnya, sehingga berdampak pada motivasi belajar yang belum maksimal. Hal ini sesuai dengan penelitian yang dilakukan oleh Rozikin dkk. (2018) yang menemukan hubungan antara minat belajar dengan prestasi belajar seorang remaja. Menurut White \& Watt (dalam Estiane, 2015) penyesuaian diri yang harus dilakukan oleh mahasiswa baru itu biasanya berkaitan dengan adanya kondisi atau proses belajar yang berbeda dengan kondisi atau prises belajar yang ada pada sekolah sebelumnya. Dimana proses pembelajaran di perguruan tingi berlangsung lebih cepat, adanya tuntutan untuk memahami materi secara detail dan mendalam, apalagi materi pembelajaran yang diajarkan berbeda dengan di sekolah menengah, perbedaan metode pengajaran yang dilakukan oleh dosen, tuntutan secara mandiri (oleh mahasiswa yang bersangkutan) untuk pengurusan administrasi perkuliahan dan sebagainya, sehingga kondisi yang demikian itu menyebabkan mahasiswa baru butuh proses dalam adaptasi untuk menghadapi perubahan-perubahan yang terjadi di perguruan tinggi tersebut.

Selain itu, bentuk dari permasalahan ini adalah adanya adaptasi dengan ma'had atau peraturan ma'had. Banyak diantara subyek penelitian ini menyampaikan hal yang sama. Hal ini lebih banyak dikarenakan latarbelakang sekolah mahasiswa sebelumnya yaitu sekolah umum seperti SMA, yang tidak sama dengan lulusan dari MA (Madrasah Aliyah) yang secara basic sudah banyak dibekali dengan keilmuan agama terlebih MA yang berada di naungan Pondok Pesantren. Oleh karena itu, ada beberapa mahasiswa baru yang terkadang merasa terbebani dengan kondisi seperti ini karena dia belajar lagi terkait manajemen waktu, penguasaan materi ma'had seperti shobahul lughoh, ta'liimul afkar dan sebagainya. Hasil penelitian yang dilakukan oleh Rohadi dkk. (2016) juga menemukan hubungan antara kemampuan untuk bradaptasi dengan lingkungan dan perilaku masyarakat pada produktivitas sebesar 33,4\%. Schneider (dalam Ali \& Asrori, 2011) juga menyampaikan bahwa setidaknya ada beberapa faktor yang dapat mempengaruhi proses penyesuaian diri remaja, salah satunya adalah faktor lingkungan, dalam hal ini adalah lingkungan fisik dan teman sebaya dalam perkuliahan. Faktor yang mempengaruhi proses penyesuaian diri selanjutnya menurut Schneider adalah proses belajar. Proses belajar termasuk faktor penting dalam proses belajar yang dapat mempengaruhi penyesuaian diri individu (dalam Iflah dan Listyasari, 2013)

c. Problematika penyesuaian diri secara sosial

Iflah dan Listysari (2013) menyatakan bahwa seseorang yang memiliki penyesuaian diri yang efektif, mampu untuk mencapai tingkat keakraban yang cocok dalam membina hubungan sosialnya. Mereka biasanya mampu dan selalu merasa nyaman ketika berinteraksi dengan orang lain sekaligus mampu mengelola serta membangun hubungan dengan orang lain. Selain itu, mereka pun akan menjadikan orang-orang di sekitarnya nyaman dengan keakraban tersebut. Namun berdasarkan hasil penelitian ini, bentuk dari permasalahan penyesuaian diri secara social ini dimana mahaasiswa baru dihadapkan pada pribadi-pribadi asing yang belum pernah ia temui sebelumnya, interaksi social lawan jenis yang sebagian mahasiswa menganggap kurang pas menurut pandangan agama, musrif (pengurus) yang kurang bisa memberi contoh yang baik (model), serta pergaulan mahasiswa yang perokok dan tidak. Permasalahan ini sendiri juga menjadi sesuatu yang umum namun perlu juga diperhatikan secara serius agar tidak memunculkan permasalahan baru di belakang hari, terlebih pada masa ini mahasiswa masih dalam kategori umur remaja yang dimungkinkan mudahnya terkena pengaruh lingkungan. Jika lingkungan social ini memberi dampak yang positif pada mahasiswa, maka tidak akan menjadikan malasah, namun jika lingkungan social tersebut memberikan dampak yang negative, tentunya akan menimbulkan masalah baru di kemudian hari. Meskipun demikian, mahasiswa yang notabene masih masuk pada fase perkembangan remaja, tetap harus menjalin hubungan yang baik dengan sesama, terutama pada teman sebaya. Menurut Halleyda (2008), agar kebutuhan seorang remaja terpenuhi dan mampu berinteraksi dengan lingkungan secara baik, maka dia harus mampu melakukan penyesuaian diri. Melalui interaksi atau pergaulan teman sebaya, seorang remaja dapat belajar tentang cara mematuhi peraturan, kesetiaan dalam pertemanan, kemandirian, tanggung jawab dalam segala hal dan lain sebagainya. Meskipun 
demikian, interaksi antar sesame remaja tersebut pasti akan mengalami kendala atau rintangan sebagai akibat dari kurangnya kemampuan dalam mengontrol emosi dan tingkah laku serta karena adanya perbedaan latar belakang kepribadian, sosial yang ada pada diri remaja (dalam Oktaviana, 2011).

Adapun Santrok (2002, dalam Iflah dan Listyasari, 2013) menyatakan bahwa seseorang akan diterima oleh kelompok atau lingkungannya jika ia mampu menyesuaikan diri dengan baik dan mampu memperlihatkan sikap atau tingkah laku yang menyenangkan.. Penyesuaian diri yang baik ini dapat terjadi ketika seorang individu sudah mampu memenuhi semua kebutuhannya, mampu menyeimbangkan kondisi diri dengan lingkungannya. Penyesuaian diri merupakan suatu proses sepanjang hidup, individu harus mampu menemukan, mengatasi problematika (tekanan) dan tantangan hidup agar menjadi individu yang sehat sekaligus mampu menyesuaikan diri dengan baik di lingkungan baru manapun.

d. Problematika penyesuaian diri secara geografis (demografis)

Secara alamiah, kehidupan itu sendiri juga mendorong manusia untuk selalu terus melakukan penyesuaian diri. Menurut Fahmi (1977) penyesuaian diri merupakan suatu proses dinamika yang terjadi secara kontinyu dengan tujuan untuk merubah tingkah laku yang lebih baik lagi agar didapatkan hubungan yang harmonis antara diri dan lingkungannya. Diantara problematika penyesuaian diri lain yang muncul pada diri mahasiswa baru adalah adanya permasalahan penyesuaian terkait geografis (demografis) yang meliputi cuaca atau iklim di kota Malang dan adat istiadat yang berbeda dengan kondisi dialami oleh mahasiswa sebelumnya. Hal ini sebagaimana yang dialami oleh subyek yang berasal dari Lombok yang menyampaikan adanya kesulitan dalam penyesuaian dengan lingkungan dikarenakan adanya perbedaan bahasa dan setting aturan sosial. Hal yang sama juga dialami oleh subyek penelitian yang harus menyesuaikan dengan kondisi cuaca dingin yang menyebabkan secara fisik terkadang mengalami gangguan dikarenakan adanya perbedaan dengan kondisi sebelumnya yang dianggapnya tidak terlalu dingin yang berpengaruh pada fisiknya tersebut. Hal yang sama disampaikan oleh Wijaya (2015) dalam penelitiannya bahwa mahasiswa rantau itu tidaklah mudah dalam melakukan penyesuaian diri. Ia harus mampu adaptasi dengan lingkungan baru dengan segala macam perbedaan latar belakang, mulai dari perbedaan secara fisik hingga perbedaan kondisi sosial. Selain itu, seorang mahasiswa juga dihadapkan pada iklim atau budaya akademik yang berbeda antara perguruan tinggi dengan iklim pendidikan sebelumnya. Apabila penyesuaian diri ini tidak berjalan dengan baik, maka akan berdampak pada kemampuan komunikasi yang kurang efektif,, tidak mandiri, lambat dalam penyesuaian diri di lingkungan baru, berubah menjadi pribadi yang negatif (seperti nakal), sering bolos dan menarik diri secara sosial (sulit bergaul dengan orang baru (dalam Fitri dan Kustanti, 2018). Kondisi kemampuan penyesuaian diri individu ini memang berbeda-beda dikarenakan berbagai hal atau factor, diantaranya kondisi psikologis, perkembangan, fisik serta lingkungan budaya (Schneider, 1960). Oleh karena itu, ketika mahasiswa dihadapkan pada lingkungan baru, maka ia juga membutuhkan dukungan social atau berinteraksi dengan baik pada lingkungannya sesuai dengan aspek-aspek temuan penelitian di atas.

2. Model penyesuaian diri mahasiswa

Hasil penelitian di atas menunjukkan bahwa problematika penyesuaian yang dihadapi oleh mahasiswa baru adalah aspek kepribadian, yaitu adanya perasan diri introvert (kurang terbuka atau kurang mampu dalam menyampaikan pendapat), peraturan mahad, jurusan yang tidak sesuai, teman sebaya yang kurang mendukung, serta lingkungan adat istiadat atau budaya yang berbeda. Oleh karena itu, bentuk penyesuaian diri secara internal yang subyek lakukan adalah dengan berusaha meningkatkan kepercayaan diri dia dengan mengikuti segala yang berlaku di lingkungan tersebut. Selain itu, subyek juga mengharapkan adanya lembaga konseling untuk bisa menangani kasus-kasus psikologis serupa dari setiap mahasiswa baru. Syam, dkk., (2017) juga menyampaikan bahwa setiap mahasiswa akan mengalami persaingan dengan sebayanya dalam menggapai prestasi yang telah dittentukan dan telah menjadi harapannya. Meskipun demikian, banyak remaja yang tidak memperoleh prestasi belajar yang baik, bahkan ada juga seorang remaja demi memperoleh prestasi yang baik, ia melakukan sesuatu yang tidak anjurkan, misalnya dengan cara menyontek. Kondisi ini semua tidak lepas dari aspek kepercayaan diri remaja yang merupakan aspek pribadi yang melekat pada dirinya itu. Tanpa adanya kepercayaan diri, maka akan menimbulkan banyak masalah pada diri seseorang (khususnya remaja), karena kepercayaan diri merupakan atribut kepribadian seseorang dalam melakukan aktualisasi segala potensi yang dimiliki. Kepercayaan diri akan tinggi jika remaja mendapatkan dukungan dari lingkungan sekitar. Jika seorang remaja memiliki sifat percaya diri yang tinggi, maka dalam berinteraksi dengan sesama, ia tidak akan mengalami kesulitan, mudah dan berani dalam menyampaikan pendapatnya, mampu berpikir dan bertindak postif dalam mengambil keputusan, memperoleh pretasi yang baik dan percaya terhadap kemampuan diri sendiri. Begitupun sebaliknya, remaja yang kepercayaan dirinya kurang, ia akan mengalami kesulitan dalam berkomunikasi, berinterkasi, merasa inferior (perasaan tidak mampu 
bersaing dengan yang lain) dan memiliki prestasi belajar yang kurang memuaskan (Syam, dkk., 2017). Hal yang sama juga diungkapkan oleh Bidjuni (2016) bahwa kepercayaan diri merupakan keyakinan seseorang terhadap kelebihan yang dimilikinya dan keyakinan tersebut membuat seseorang tersebut merasa mampu untuk mencapai berbagai tujuan hidupnya sekaligus memudahkan dirinya untuk beradaptasi dengan lingkungan sekitar. Komara (2016) dalam penelitiannya juga menemukan adanya hubungan yang positif antara kepercayaan diri dengan prestasi belajar. Semakin tinggi kepercayaan diri, maka semakin tinggi pula prestasi belajar remaja. Komara menambahkan bahwa kepercayaan diri adalah karakteristik pribadi seseorang yang di dalamnya terdapat keyakinan akan kemampuan diri dan mampu mengembangkan serta mengolah dirinya sebagai pribadi yang mampu menanggulangi suatu masalah dengan situasi terbaik.

Selain model penyesuaian diri dengan meningkatkan rasa percaya diri sebagaimana penjelasan di atas, subyek penelitian juga melakukan penyadaran diri (self awareness) dengan cara membuat skala prioritas model goal setting terkait dengan tujuan dan harapan atas kegiatan yang sedang dijalaninya. Menurut Gibson, dkk. (1985) goal setting merupakan penetapan sasaran atau tujuan tertentu yang akan dilaksanakan dalam suatu periode tertentu pula (dalam Irmawati, 2004). Tujuan (goal) dapat mengantarkan seorang remaja dalam mencapai performansi yang telah ditetapkan memalui empat hal. 1) melalui goal atau tujuan perhatian dan tindakan seseorang dapat diarahkan kepada tugas yang relevan demi tercapainya sebuah prestasi. 2) sebuah goal atau tujuan dapat berfungsi sebagai energi yang dapat menggerakkan usaha sesorang untuk mencapai performansi. 3) Tujuan dapat mempengaruhi ketekunan seseorang 4) Tujuan juga dapat mempengaruhi tindakan seseorang untuk pencarian pengetahuan, penggunaan dan strategi yang relevan dalam rangka menyelesaikan tugas (Locke \& Latham, 2002).

Goal theory membagi tujuan menjadi beberapa tujuan, antara lain: learning goal, performance goal dan do your best goal atau general goal (Schunk, 2008 dalam Affandi dan Hastjarjo, 2011):

a. Learning Goal : namanya, learning goal merupakan penentuan tujuan yang dibingkai untuk memfokuskan pada pengembangan pengetahuan, keterampilan akan suatu tugas serta penguasaan tugas (Schunk, 2008; Seijts dan kawan-kawan, 2004;). Fokus learning goal terletak pada proses dan bukan pada hasil akhir (Kanfer \& Ackerman, 1989).

b. Performance Goal: performance goal merupakan bagian dari teori achievement goal, dimana performance goal diartikan sebagai tujuan yang mendemonstrasikan kemampuan atau menghindari untuk menunjukkan kemampuan yang dirasa tidak mampu dilakukan (Midgley dan kawan-kawan, 2001). Fokus performance goal terletak pada penyelesaian tugas (Schunk,2008).

c. Do Your Best Goal (General Goal): diartikan sebagai tujuan yang lebih bersifat umum (Winter \& Latham, 1996). Tujuan ini mengarahkan seseorang untuk mengerjakan tugas yang diberikan sebaik mungkin, dan untuk mencapai tujuan tersebut partisipan diberikan instruksi untuk mengerjakan tugas yang diberikan sebaik mungkin (Drach-Zahavy, \& Erez, 2002; Fried, \& Slowik, 2004).

\section{Kesimpulan}

Penelitian ini mendapatkan hasil adanya problematika penyesuaian diri yang meliputi aspek psikologis, akademis, sosial dan demografis. Sementara penyelesaian permasalahan penyesuaian diri ini diantaranya melalui aspek internal (yakni dengan cara individu atau mahasiswa tersebut membuat goal setting, manajemen diri ataupun berinteraksi sosial dengan baik) dan aspek eksternal (yakni adanya kebutuhan untuk didampingi secara psikologis dan perlu adanya unit layanan konseling dari lembaga/universitas).

\section{Daftar Pustaka}

Affandi, Ghozali Rusyid, dan Hastjarjo, Thomas Dicky.(2011). Pengaruh Tipe Penentuan Tujuan (Goal Setting) Terhadap Performansi Bahasa Inggris Siswa: Dengan Efikasi Diri Dan Kemampuan Awal Bahasa Inggris Sebagai Kovariabel. Jurnal Psikologi. Volume 6 Nomor 1

Arikunto, Suharsimi, (1998), ProsedurPenelitian, suatu pendekatan praktek, Jakarta: PT. Rineka Cipta. Bidjuni, Hendro.(2016). Hubungan Kepercayaan Diri dengan Penyesuaian Diri Pada Mahasiswa Baru Di Program Studi Ilmu Keperawatan Fakultas Kedokteran Universitas Sam Ratulangi Manado. eJurnal Keperawatan Volume 4 Nomor 2.

Estiane, Uthia. (2015). Pengaruh Dukungan Sosial Sahabat Terhadap Penyesuaian Sosial Mahasiswa Baru di Lingkungan Perguruan Tinggi. Jurnal Psikologi Klinis dan Kesehatan Mental. Surabaya Fahmi, Mustafa. (1977). Kesehatan Jiwa dalam Keluarga, Sekolah dan Masyarakat. Bulan Bintang. Faisal, Sanapiah, (1990), Penelitian Kualitatif, dasar-dasar dan aplikasi, Malang, YA3 IKIP. Fatimah, Enung. (2006). Psikologi Perkembangan. Bandung: CV Pustaka Setia. 
Fitri, Rayhanatul, dan Kustanti, Erin Ratna. (2018). Hubungan antara efikasi diri akademik Dengan penyesuaian diri akademik pada mahasiswa rantau dari Indonesia Bagian timur di Semarang. Semarang. Jurnal Empati Volume 7 (Nomor 2).

Fortin Laurier, dkk., (2006). Typology of students at risk of dropping out of school: Description by personal, family and school factors. European Journal of Psychology of Education. Vol. XXI, no 4, 363-383

Hamidi. (2005). Metode Penelitian Kualitatif Aplikasi Praktis Pembuatan Proposal dan Laporan Penelitian. Malang: UMM Press.

Handayani, Penny \& Azura, Anissa. (2018). Program Pendampingan Psikologis Bagi Remaja Psaa Ceger Dan Tebet, Jakarta: Analisis Kebutuhan. Jurnal Mitra Vol. 2 No.1

Hermawan, Trian. (2010). Makalah Pengenalan Peserta Didik (Penyesuaian Diri Dan Permasalahan Pada Remaja. Program Study Pendidikan Fisika Fakultas Keguruan Dan Ilmu Pendidikan Universitas Lampung. Bandar Lampung.

Hurlock, E. B. (1991). Psikolgi Perkembangan Suatu Pendekatan Sepanjang Rentang Kehidupan(Terjemahan oleh Istiwidayanti dan Soedjarwo). Jakarta: Erlangga.

Iflah dan Listyasari, Winda Dwi. (2013). Gambaran Penyesuaian diri Mahasiswa Baru. Jurnal Penelitian dan Pengukuran Psikologi. Volume 2 No 1.

Irmawati. (2014). Peranan Goal Setting Dalam Upaya Meningkatkan Produktivitas Kerja Karyawan. Fakultas Ilmu Sosial Dan Ilmu Politik Universitas Sumatera Utara. USU digital library

Irfan, M dan Suprapti, Veronika. (2014). Hubungan Self Efficacy dengan Penyesuaian Diri terhadap Perguruan Tinggi pada Mahasiswa Baru Fakultas Psikologi Universitas Airlangga. Jurnal Psikologi Pendidikan dan Perkembangan. Volume 3 No 3.

Kamaluddin. (2011). Bimbingan dan Konseling Sekolah. Jurnal Pendidikan dan Kebudayaan, Vol. 17, Nomor 4, Juli 2011

Kumalasari, Fani dan Ahyani Latifa Nur. (2012). Hubungan antara Dukungan Sosial dengan Penyesuaian Diri Remaja di Panti Asuhan. Jurnal Psikologi Pitutur, Volume 1 No 1

Komara, Indra Bangkit.(2016). Hubungan antara Kepercayaan Diri dengan Prestasi Belajar dan Perencanaan Karir Siswa. Jurnal Psikopedagogia. Volume 5 No 1, 36

Locke, E. A., \& Latham, G. P. (2002). Building a practically useful theory of goal setting and task motivation: A 35-year odyssey. American Psychologist, 57, 705-717

Mapiare, Andi. (1982). Psikologi Remaja. Surabaya: Usaha Nasional.

Moleong, Lexy J. (1994). Metode Penelitian Kualitatif, Bandung, Remaja Rosdakarya.

Muchdhoero, Mohyi. (1993).Metodologi Penelitian untuk ilmu-ilmu Ekonomi dan Sosial, Malang, UMM Press.

Mu'tadin, Zainun. (2002). Penyesuaian Diri Remaja. Jakarta: http:/www.e psikologi.com/zainun.htm.

Patton. (2002). EQ Pengembangan Sukses Lebih Bermakna. Mitra Media.

Poerwandari, E. Kristi, dkk. 2005. Pendekatan Kualitatif untuk Penelitian Perilaku manusia, Jakarta, Lembaga Pengembangan Sarana Pengukuran dan Pendidikan Psikologi.

Santrok, John. W. (2003). Adolescence (Perkembangan Remaja). Terjemahan. Jakarta: Penerbit Erlangga. Santrok.(2007). Remaja (Edisi kesebelas, Jilid 1). Terjemahan.. Jakarta: Penerbit Erlangga.

Sarwono, S. (2011). Psikologi Remaja. Jakarta: PT. Rajagrafindo Persada.

Schneider. Alexander A.(1960). Personal Adjustment and Mental Health. New York.

Strauss, A dan Corbin, Juliet. (1997). Dasar-dasar Penelitian Kulaitatif, prosedur-prosedur teknik dan teori graunded, Surabaya, Bima Ilmu.

Sunarto dan Agung Hartono. (1994). Perkembangan Peserta Didik. Jakarta: Departemen Pendidikan dan Kebudayaan.

Syam, Asrullah., dan Amri. (2017). Pengaruh Kepercayaan Diri (Self Confidence) berbasis Kaderisasi IMM terhadap Prestasi Belajar Mahasiswa (Studi Kasus di Program Studi Pendidikan Biologi Fakultas Keguruan dan Ilmu Pendidikan Universitas Muhammadiyah Parepare). Jurnal Biotek. Volume 5 no 1.

Wahidmurni. (2008). Cara Mudah Menulis Proposal dan Laporan Penelitian Lapangan. Malang: UM Press. 